\title{
Learning Ownership Regulations in China through Networks: A Framework on Its Role in Flexibility and Post-entry Mode Change
}

\author{
Hua Ye \\ Graduate School of Business Administration, Ritsumeikan University \\ 1-1-1Noji Higashi, Kusatsu, Shiga 525-8577, Japan \\ Tel: +81-080-4026-1915Ｅ-mail:gr0038xv@ed.ritsumei.ac.jp, tinayehua@yahoo.com.cn
}

Received: June 3, $2011 \quad$ Accepted: July 14, $2011 \quad$ Published: January 5, 2012

doi:10.5430/ijba.v3n1p41 URL: http://dx.doi.org/10.5430/ijba.v3n1p41

The research is sponsored by Research Fund for Accelerating International Research Activities of Ritsumeikan University in Japan.

\begin{abstract}
This research reviewed literature on networks, learning, internationalization and flexibility, defined post-entry mode change, and then proposed a theoretical framework. This framework highlights learning ownership regulations in China through networks and its impact on flexibility and in turn post-entry mode change.
\end{abstract}

Keywords: Networks, Learning, Ownership Regulations, Flexibility, Entry Mode

\section{Introduction}

Networks are treated as a source of accessing external resources (Giarratana \& Torrisi, 2010), or directly as an external resource (Hakansson \& Snehota, 1989; Gulati, 1999), or as institutions (Ghoshal \& Bartlett, 1990), or as organizational forms (Powell, 1990).

Networks are becoming increasingly more involved in international business studies, as firms are increasingly adopting network forms of organization and are subject to influences of non-economic factors (Powell, 1990). Johanson \& Vahlne (2009) revised their original model of internationalization to a business network model, demonstrating the importance of network relationships in internationalization activities. Post-entry mode change is operation mode change after the initial entry into a foreign market. Both the initial entry mode choice and the post-entry mode change are important internationalization activities. While the impact of networks on entry mode choice has been extensively studied but inconclusively, little research has explicitly highlighted the link between networks and post-entry mode change.

China began to attract FDI with an Open Door policy of 1982 and further promulgated "Provisions for the Encouragement of Foreign Investment" in 1986 and 1987. Due to ownership regulations of the Chinese government, joint ventures (JVs) are the oldest and most popular form in China (Beamish, 1993). Equity joint ventures (EJVs) were the dominant foreign entry strategy before 1997 (Xia, Tan, \&Tan, 2008). However, these ownership regulations have been changing.

Networks are a source of learning and extracting information (Hagedoorn \& Duysters, 2002), especially, learning about markets and institutions in the host country (Rangan, 2000). To survive and grow after initial entry into a foreign market, the multinational corporation (MNC) needs to develop or attract outside complementary assets such as marketing and distribution capabilities (Teece, 1986). Networks provide a source of attracting outside complementary assets, which could also include the capability of learning ownership regulations. Here, learning ownership regulations refers to acquiring, interpreting and confirming ownership regulations of foreign investment. On the other hand, networks could constrain learning (Nooteboom, 2004). However, following the advocates of Johanson \& Vahlne (2009), we regard networks as vehicles in learning institutional conditions, specifically, learning ownership regulations in China. Thus, learning ownership regulations through networks is demonstrated.

MNC flexibility in this research is defined as the MNC's ability to manage the risks and exploit the opportunities that arise from the changing ownership regulations of foreign investment in China. Learning about risks and opportunities that arise from such ownership regulations can be essential to managing these risks and exploiting these opportunities. 
As a result, learning ownership regulations can influence MNC flexibility. In turn, the MNC's ability to manage these risks and exploit these opportunities can exert impacts over ownership-related strategic choice. Thus, MNC flexibility can affect post-entry mode change.

In order to explore how learning ownership regulations in China through networks can impact on MNC flexibility and in turn post-entry mode change, we will develop a theoretical framework. Firstly, we will review relevant literature and clarify related concepts. Then a theoretical framework will be proposed and illustrated.

\section{Embeddedness and Networks}

Embeddedness refers to "the fact of exchanges within a group...have an ongoing social structure...by constraining the set of actions available to the individual actors and by changing the dispositions of those actors toward the actions they may take...”(Marsden, 1981:1210, in Uzzi, 1996). Granovetter (1985) criticized “markets and hierarchies” arguments that treat social structural impacts on market behavior as exceptions, and combined the embeddedness approach with the economic approach. The combination can better explain economic behavior and competitiveness than the pure economic approach (Uzzi, 1997). Embedded ties refer to ongoing and exclusive relationships with one another. A lot research has involved features of embedded ties, for example, trust and personal ties (Smitka, 1991), thick information exchange of tacit and proprietary know-how (Helper, 1990), coordination devices promoting knowledge transferring and learning (Larson, 1992), long-term, cooperative ties (Romo \& Schwartz, 1995), trust, fine-grained information transfer and joint problem-solving arrangements (Uzzi, 1996, 1997). These features create competitive advantages for firms and their networks.

Powell (1990) divided inter-firm exchanges into market ties and network ties. The former are impersonal and constantly changing exchange partners; the latter are stable and keeping close social relationships. Impersonal market transactions become concentrated and exclusive, forming dyadic embedded ties, which assemble into extended networks of embedded ties. By this means, each firm's ties and ties of these ties form an organization network (Uzzi, 1997). That is to say, the organization is embedded in a number of relationships with identifiable counterparts and this web of relationships can be called a network. Halinen \& Tornroos (1998) utilized the embeddedness perspective to describe and explain network dynamics and suggested that networks emerge and evolve via processes of continuous interaction. Thus, the network means the context of organizations is a concentrated and structured kind (Hakansson \& Snehota, 1989).

The embeddedness perspective, which highlights the salience of networks, is applicable to both individual and interorganizational networks. The embeddedness perspective was firstly applied to the study of individuals and their networks and later to firms and their interorganizational networks (Gulati, 1999). Embeddedness can often be established in new relationships due to such social circles as colleagues, schoolmates, friends or kin, as third-party referral networks and previous personal relations are often sources of embeddedness.

\subsection{Inter-Firm Networks}

Early IMP (International Marketing and Purchasing) models focused on business networks only with inter-firm exchange relations (Hakansson \& Snehota, 2000). Networks are seen as structures of inter-firm relationships in industrial networks (Halinen \& Tornroos, 1998). Madhok (1997) and Parke (1993) considered inter-firm relations as economic exchanges due to rational calculation for each member's resource needs. Forsgren, Holm, \& Johanson (2005) and Andersson, Forsgren, \& Holm (2002) focused on business networks of market exchange relations with suppliers and customers. Coviello \& Munro (1997) examined the small MNC's network relationship with large MNCs to which it distributed.

One of the important and broadly studied inter-firm networks are strategic alliance networks (Madhavan, Koka, \& Prescott, 1998). A strategic alliance is an agreement between two or more partners to share knowledge or resources which could be beneficial to all parties involved, shaped from technology and product development to manufacturing and marketing (Vyas, Shelburn, \& Rogers, 1995). Along its structural spectrum, joint ventures occupy one end, with partners creating a new entity in which they share equity and most closely replicate the hierarchical control features of organizations, and at the other end, alliances without sharing of equity and with few hierarchical controls, i.e. alliances with arm's-length contracts (Gulati \& Singh, 1998). Strategic alliance networks are seen as a type of organizational form (Sydow \& Windeler, 1998) or as a source of resources called network resources (Gulati, 1999). Organizations in the strategic alliance network tend to create stable, preferential relationships characterized by trust and rich information exchange with specific partners, decreasing search costs and the risk of opportunism (Powell, 1990).

Inter-firm networks include not only the focal firm's relations with actual exchange partners but also with third parties such as law firms, banks, marketing or technical consultants (Hallen, 1992). In other words, task-oriented relations both directly and indirectly connected to a specific business transaction create an inter-firm network structure. 
Gomes-Casseres (1990) suggested that MNCs can acquire information on host country ownership regulations through the market by hiring services of law consultant companies representing the MNC in negotiations with government. Ojala (2009) suggested that the important business relationships in a focal firm's network are often those with non-for-profit government-owned consulting firms, which mediate between the firm and its potential business partners.

\subsection{Infrastructural Networks}

The third generation IMP research extends to networks with a variety of relationships (Welch \& Wilkinson, 2004). Thus, networks can be specified to different types and dimensions, including social, market, regional, technological, institutional and infrastructural networks, as well as temporal, spatial and representational dimensions (Fletcher \& Barrett, 2001). Institutional networks, which involve environmental groups, communications bodies, and the media, can be closely associated with social networks and are often structures for interpersonal communication. Network ties link various actors, e.g. business partners, friends, agents, and mentors (Uzzi, 1997). Moreover, different kinds of exchanges can be established and maintained in different ways, such as integrating government agencies, using trust-based relationships and mediating roles of organizations like law consultants and business associations (Ghoshal \& Bartlett, 1990). Correspondingly, embeddedness takes a variety of forms and thus refers to a company's relations with and reliance on various types of networks (Halinen \& Tornroos, 1998). Granovetter (1985) argued that all economic action is embedded in networks of social relations. In other words, networks of social relations both between and within firms are overlaid on business relations. Even business network approach itself originates from social network and behavioral theory (Hadjikhani \& Ghauri, 2001). Halinen \& Tornroos (1998) treated business networks as complex embedded structures of inter-firm relationships in that these relationships are embedded in broader contextual settings. Business networks in early IMP research composed only of business actors such as customers, suppliers, distributors and competitors are expanded to a broader concept. Hallen (1992) identified three levels of business networks, i.e. inter-firm networks, organization-centered infrastructural networks, and person-centered infrastructural networks. Infrastructural networks are networks infrastructural to inter-firm networks and composed of non-task relationships with nonbusiness actors, growing either around the firm's business activities or around specific individuals.

Organization-centered infrastructural networks include a focal firm's relationships with nonbusiness actors such as government, trade unions, industrial federations and private-interest associations. Person-centered infrastructural networks develop around specific individuals both as businessmen and as private persons, i.e. managerial ties defined as executives' interpersonal contacts with external entities (Peng \& Luo, 2000; Zhang \& Li, 2008). The embedded tie composed of two organizations is complex as it consists of a web of interactive relations between individuals in both organizations (Hakansson \& Snehota, 1989). Besides business ties, managers' interpersonal relations include family and community ties, school and university ties, banking and boardroom ties, chamber of commerce and trade association ties, and employer and co-worker ties. Contrasted with organization-centered infrastructural networks, the person-centered ones have denser and closer ties (Hallen, 1992). It may explain the conclusions that managerial ties with top executives of other firms and with government officials can improve firm performance (Peng \& Luo, 2000) and that managerial ties in emerging economies greatly influence firm growth (Zhang \& Li, 2008). Particularly, some activities in China like interpreting regulations rely heavily on managerial ties (Peng \& Luo, 2000).

A firm's management activity is divided into business area considering interaction with business actors and political area involving interaction with nonbusiness actors (Boddewyn, 1988). Business activity and political activity coexist and are complementary (Hadjikhani \& Ghauri, 2001). Network is a set of socially and economically interrelated actors, i.e. both business and nonbusiness actors (Hadjikhani, 2000). While the business network may be composed only of business actors on one hand (Forsgren, Holm, \& Johanson, 2005), political actors constitute the political network on the other hand. Political actors include bureaucrats, government ministers, parliament members, opposition parties, interest groups and the media (Hadjikhani \& Hakansson, 1996). Often associated with institutional network, political network features by temporality and discontinuity, versus longevity of industrial network. In other words, firms' political activity is influenced by the loose structure of political network. In contrast, Hadjikhani (2000) incorporated political actors into the business network and highlighted their proactive effect on business actors. Political actors may occupy important positions in the business network, particularly when the country MNCs enter has a more planned economy or is run by a more interventionist government. Thus, political actors play various roles in the business network (Jansson, Saqib, \& Sharma, 1995; Hadjikhani \& Hakansson, 1996) and in fact constitute infrastructural network that Hallen (1992) has named.

Isolating political actors from business actors and exchanges is far from reality (Hadjikhani \& Sharma, 1999, in Welch \& Wilkinson, 2004), whether the political actors are assigned to political network or business network. A stream of research has studied how political actors influence business actors (e.g. Moran, 1985). Another stream studied the effect 
of business actors on political actors (e.g. Austen-Smith, 1987). Furthermore, a group of studies consider interaction between political and business actors (e.g. Boddewyn, 1988). Governments distribute regulations and supportive measures for firms while firms satisfy people and groups for whom governments are responsible.

Since a single exchange is embedded in not only business ties but also social and political ties (Hallen, 1992; Halinen \& Tornroos, 1998; Welch \& Wilkinson, 2004), so is a single firm. That is, a firm is embedded in networks composed of business relations, political relations, as well as social relations. A firm's commitments in business, political and social relations decide the type of support it can achieve in a foreign market (Hadjikhani, 2000).

\subsection{Networks of Multinational Corporations (MNCs)}

MNCs are treated as networks of both internalized relationships and externalized relationships by Dicken (1998). Similarly, Ghoshal \& Bartlett (1990) conceptualized a MNC as a multinational network embedded in an external network. Multinational network refers to a network of exchange relationships among headquarters and subunits. It is in fact internal network of a MNC involving diversified resource exchanges such as technology, people and information. Externally, a MNC tends to be embedded in differentiated networks simultaneously, as different units of the same MNC are embedded in different national organization sets. The different local networks constitute the MNC's external network. MNCs' network formation is affected by their adjustments to industrial strategies of states. Industrial policy changes have exerted effects over the network formation through MNCs' international systems. MNCs rent their networks to the host countries of command and the transitional economies to compensate underdeveloped organizational resources in these countries (Kogut, 1983, in Murtha \& Lenway, 1994).

Within the MNC, subunits with various functions exchange information horizontally with each other and vertically with the headquarters, thus forming a communication network or differentiated network internally (Ghoshal \& Nohria, 1997, in Forsgren, Holm, \& Johanson, 2005). Externally, the MNC collaborates with other business partners while handling relationships and information with organizations such as major business service providers (financial, legal or advertising) and major governmental departments.

Relationships between internal subunits are regarded as either inter-organizational (Ghoshal \& Bartlett, 1990) or intra-organizational (Dicken, 1998). Forsgren, Holm, \& Johanson (2005) argued that internal units are not significantly different from external units to the individual subsidiary, as the subsidiary may depend on local actors to the same extent as or even more than on sister subsidiaries and headquarters. Similarly, we treat equal the units both internal and external an MNC. In other words, a focal subsidiary's relationships with other internal units are treated as inter-organizational. In addition, complying with Ghoshal \& Bartlett (1990), we consider not only the focal subsidiary's relationships with internal and external business partners, but also its relationships with nonbusiness actors. Thus, the internal business units (headquarters and sister subsidiaries) as well as external business partners and nonbusiness actors constitute a focal subsidiary's network of inter-organizational relations, which we call inter-organizational network.

Among the nonbusiness actors of organizational level, the government attracts most attention. Features of MNC-government relations include frequent contact, dominance of information exchange, high-level and long-term social interaction and trust (Jansson, Saqib, \& Sharma, 1995). Nonetheless, Welch \& Wilkinson (2004) utilized policy-business networks to classify the link between political and business actors into two forms: one spectrum as stable and close relationships with frequent resource exchange and the other as unstable relationships with unequal resources. MNCs and the government depend on each other, as businesses are affected by political rules and on the other hand, foreign businesses impact on such actors as the media and the public which government relies on.

\section{Networks, Learning and Internationalization}

\subsection{Entry Mode Choice and Post-entry Mode Change}

Foreign market entry mode is defined as “an institutional arrangement that makes possible the entry of a company's products, technology, human skills, management, or other resources into a foreign country” (Root, 1994: 5). It is a long-researched topic from a variety of views. Brouthers \& Hennart (2007) reviewed previous empirical studies and concluded that the most frequently used theories explaining entry mode choice decision were transaction cost analysis (TCA), the resource-based view, institutional theory and OLI framework. In addition, such theories as bargaining power and resource dependency were also applied. Fetscherin, Voss, \& Gugler (2010) investigated research of the past 30 years on FDI to China and classified the entry and expansion strategies into "inside the multinationals", contrasted with "motives and determinants of FDI to China", “ impact of MNE activities", and " policy implications for the host country".

Although there has been a lot research on initial entry mode choice, relatively little is studied about post-entry change of foreign firms' ownership forms, i.e. changes in ownership forms of operation abroad after initial entry (Puck, 
Holtbrugge, \& Mohr, 2009). Uppsala School advocates that the process of internationalization is incremental in the sequence of "export via an agent-sales subsidiary (acquisition of the agent or organized around employees of the agent)—local production” (Johanson \& Vahlne, 1977). In other words, if a MNC chooses export as the initial entry mode, it will convert export to sales subsidiary, and later change sales subsidiary to local production. According to Buckley \& Casson (1981), the evolution of MNC entry modes is from export to licensing to FDI, but the MNC may expand directly from exporting to FDI skipping licensing in some cases, and in other cases, may evolve only from exporting to licensing but not from licensing to FDI. Thus, if the MNC chooses export when entering the foreign market, it may switch from export to licensing and later to FDI, or directly from export to FDI, or only from export to licensing. The "post-entry changes of ownership forms", "process of internationalization", and "evolution of MNC entry modes", all indicate the way by which MNCs may change their operation modes after initially entering the foreign markets. We term this "post-entry mode change", which is defined as the MNC changes its mode of operation after initial entry into a foreign market. Correspondingly, we define "status of post-entry mode change" as whether or not the MNC changes its mode of operation after initial entry into a foreign market.

In this research, post-entry mode change is specified as the MNC changes to wholly foreign-owned enterprise (WFOE) after initial entry as joint venture (JV, including Chinese-foreign Cooperative Enterprise, Chinese-foreign JV and International JV). In his study of entry mode choice between joint venture and wholly-owned subsidiary, Hennart (1991) suggested that although Japanese MNCs are well-known for their preference to set up joint ventures at the point of entry, these joint ventures tend to become wholly-owned subsidiaries as they age, especially in production industry. That is to say, the Japanese MNCs prefer post-entry mode change from initial joint venture to wholly foreign-owned enterprise. However, our study on Toyo Keizai database (2010 version) as well as company websites has shown that most of these Japanese subsidiaries have kept JVs rather than changing to WFOEs, e.g. only around $11.2 \%$ of Japanese JVs established in Shanghai during 1980s and 1990s were changed to WFOEs in 2000s.

\subsection{Networks and Internationalization}

Both entry mode choice and post-entry mode change can be assigned to internationalization activities. The link between networks and internationalization of firms has been studied extensively. Networks have been widely used to explain the internationalization of firms in various industry segments. The environment particularly political environment, in which relationship networks become embedded, is influential in the internationalization (Fletcher \& Barrett, 2001). Network relationships for entering foreign markets can be divided into different types, e.g. formal, informal (Coviello \& Munro, 1997) and intermediary (Chetty \& Holm, 2000).

Although passive networking is useful as the result of an initiative taken by such actor as a customer, importer, intermediate or supplier that can open new opportunities in foreign markets (Johanson \& Vahlne, 2003), a firm without suitable network relationships can take an active role and build new connections to facilitate its market entry (Loane \& Bell, 2006). Coviello \& Munro (1997) found that each case firm's foreign market selection and entry mode choice has been impacted by network relationships. Coviello \& Martin (1999) demonstrated the important role of formal and informal network relationships in initial market selections and entry mode choice. Moen, Gavlen, \& Endresen (2004) and Zain \& Ng (2006) discovered that network relationships impact on entry mode and market selection and thus internationalization process. Particularly, relationships between MNCs and political actors such as governments are increasingly considered crucial to foreign market entry and growth (Welch \& Wilkinson, 2004). In contrast, Ojala (2009) concluded that market selection and entry mode decision is for strategic reasons rather than following network relationships. Sharma \& Blomstermo (2003) indicated that internationalization process is influenced by network relations but entry mode choice is based on the requirements of the market and the client in question. Bell (1995) suggested that market selection is related to network contacts while entry mode choice is more related to product attributes.

Nevertheless, little research has explicitly studied the impact of network relationships on post-entry mode change, a critical internationalization activity for the MNC's survival or growth after initial foreign market entry.

\subsection{Network Embeddedness and Learning}

Information is among the most important functions of a firm's networks. Information flow is a type of network resource flows. Inter-firm linkages provide access to partner resources in collaboration networks (Gulati, 1995). A MNC subsidiary may access internal resources held by connected actors in a network (Nohria, 1992, in Gnyawali \& Madhavan, 2001). These resources also include information. The information flow includes not only information and knowledge gathered from connected firms about their competitive intent, strategies, and resources (Harrigan, 1986, in Gnyawali \& Madhavan, 2001), but also information from connected nonbusiness actors. When inter-firm relations are absent, infrastructural networks are essential to obtain information. Social networks make information not only transferable but 
also interpretable and valuable (Uzzi, 1996). Wide and deep interpersonal business and private relationships bring about cheap, expeditious and effective information (Rangan, 2000). Thus, infrastructural networks can be even more important than inter-firm networks.

A number of scholars have emphasized the learning benefits of network forms of organization (Powell, 1990; Uzzi, 1997; Hamel, 1991). The essence is information benefits of relationship networks. Network forms of organization foster learning because they preserve greater diversity of search routines than hierarchies and convey richer, more complex information than markets. They can encourage learning by promoting the rapid transfer of self-contained information. In this view, network ties are conduits or channels of information transfer (Hamel, 1991). The most useful information is obtained from network embedded ties, i.e. "someone you have dealt with in the past and found to be reliable" (Powell, 1990). Embedded ties help acquire information with veracity and meaning beyond its face value (Uzzi, 1997). Thicker information transferred through embedded ties fosters learning in different ways from arm's length ties (Larson, 1992). Key relationships in the network should result in more learning, less bias in decision making, and greater personal growth and balance (Cross and Thomas, 2011). Coghlan and Coughlan (2011) highlighted the network of learning, in which firms develop trust of others and confidence in their own capabilities to learn.

Thus, networks and embeddedness influence learning, which is defined in this research as information obtaining, interpreting and confirming.

\subsection{Networks and Foreign Institutional Knowledge}

The Uppsala model suggests that a prerequisite for international operations is the development of knowledge of international markets. Such knowledge can be classified into objective knowledge easily acquired and experiential knowledge that firms can acquire only through engaging in international operations (Johanson \& Vahlne, 1977). The MNC's initial entry into foreign market can help obtain experiential knowledge. Eriksson et al. (2000) described experiential knowledge as the MNC's learning capacity, including among other things institutional knowledge of the host country.

Foreign institutional knowledge, which refers to experiential knowledge of government, institutional framework, rules, norms and values, is an essential component of experiential market knowledge (Eriksson et al., 1997). It concerns institutions found in foreign markets, foreign governments and bureaucracies, and the ways in which these work. Policy learning is among foreign institutional knowledge. As an essential part of knowledge about foreign market, policy learning "involved identifying important decision-makers, understanding the process of policy formation and reform, adapting to the country's political institutions, keeping informed about policy changes, and building infrastructural networks" (Welch \& Wilkinson, 2004: 224). It is insufficient to understand technical and commercial laws and norms in a foreign market without experiential institutional knowledge, as law enforcement in practice is even more important than what the law says. Consequently, foreign institutional knowledge is a source of competitive advantage (Murtha \& Lenway, 1994).

One important source that foreign subsidiaries in emerging markets use to acquire foreign institutional knowledge is their networks (Elango \& Pattnaik, 2007). Knowledge about host government policy can potentially be acquired from other actors in various types of networks. MNCs could learn from these network relationships, a source of critical knowledge for internationalization (Chetty \& Eriksson, 2002). For instance, business actors can obtain experience and information about values and activities of political actors through interaction with them (Hadjikhani \& Ghauri, 2001). In this way, MNC subsidiaries obtain information on host government policy by building up direct relationships with the government. On the other hand, a firm can access wider knowledge base through its network of important suppliers, customers and other business partners (Kogut, 2000). If the knowledge base could also contain information on host government policy such as ownership regulations, the firm's business partners may become the intermediate in its relationship with government. By this means, MNC subsidiaries acquire information on government policy indirectly from their business partners. Moreover, personal ties are overlaid on the above direct and indirect relations. Thus, business partners, government and relevant persons can become constituents in a MNC subsidiary's networks of learning host government policy. These networks for learning include inter-firm networks composed of relations with business partners, organization-centered and person-centered infrastructural networks.

\subsection{Learning and Internationalization}

The internationalization theory asserts that a firm's level of commitment increases with accumulation of experiential knowledge about the host market (Johanson \& Vahlne, 1977). Accordingly, a positive link exists between learning host market and mode choice. A firm with little experiential knowledge on the host country needs to acquire local knowledge by partnering with local firms (Barkema, Bell, \& Pennings, 1996). As more experience and knowledge are gained in a 
host country, the firm develops its capability to operate independently in the host country (Delios \& Beamish, 1999). For instance, less experiential knowledge at the point of initial entry leads to choice of joint venture, the lower-commitment mode. With accumulation of experiential knowledge and without inhibition of government policy, the joint venture is probably changed to wholly owned subsidiary, the higher-commitment mode. Thus, learning host market can be connected with post-entry mode change. Learning host market encompasses a broad array of host country characteristics, e.g. political and legal rules, the social norms for business transactions.

In contrast, some studies point to a negative relationship between foreign experiential knowledge and reliance on wholly owned subsidiaries (e.g. Hedlund \& Kverneland, 1985). In addition, Erramilli (1991) supported a U-shaped relationship between experiential knowledge and propensity for high-control entry modes. Thus, no conclusion can be made about the link between learning host market and entry mode choice or post-entry mode change.

\section{MNC Flexibility}

Flexibility is a subject researched by a wide range of disciplines, from military strategy and economics, through strategic management and decision theory, to child psychology and environmental research. Flexibility is also a multi-faceted concept, including adaptability, versatility, resilience, and robustness (Bahrami \& Evans, 2005). In other words, the content assigned to the concept varies from one author to another. Bruce Kogut (1985) argued that the MNC needs to create operational flexibility in order to profit from global strategies. Accordingly, it is also termed as strategic flexibility of the MNC. The concept of operational/strategic flexibility proposed by Bruce Kogut is captured and termed as multinational flexibility by Bartlett, Ghoshal, \& Beamish (2008). They define multinational flexibility as the ability of a company to manage the risks and exploit the opportunities that arise from the diversity and volatility of the global environment. We comply with this definition. Nevertheless, as we focus on the changing institutional environment in China, specifically, the changing ownership regulations, we term this concept as MNC flexibility and redefine it as the MNC's ability to manage the risks and exploit the opportunities that arise from the changing ownership regulations in China, i.e. the diversity and volatility of a specified institutional environment in a specified country rather than that of general environment in the globe.

\section{Institutional Environment in China}

Institutional transitions refer to fundamental and comprehensive changes introduced to the formal and informal rules which affect organizational activities. As command economies make transition toward markets, institutional compatibility with international economy may improve. Transitions toward market-based economies have led to changes in the institutional environment in China, such as weakened bureaucratic controls and tolerance of private ownership (Peng, 1994, in Peng \& Heath, 1996). However, the transition process has been volatile and uncertain without an adequate legal framework and a stable political structure (Peng \& Heath, 1996). For example, ownership regulations of foreign investment in China have been changing. Chinese government launched Law of Wholly Foreign-owned Enterprises in 1986, permitting MNCs to establish wholly foreign-owned enterprises (WFOEs) for the first time. At that time, however, WFOEs were allowed only in a few industries. Some industries were still closed to foreign investment and some were only opened for JVs stipulating that Chinese State-owned Enterprises (SOEs) should hold majority share. Until 1995, the most prominent ownership laws "Regulations for Guiding the Direction of Foreign Investment" and its appendix "Catalogue for Guiding Foreign Investment in Industries" were issued. The former categorizes Chinese industries into those that are encouraged, permitted, restricted and prohibited for foreign investment and was revised in 2002. The latter was revised in 1997, 2002, 2004 and 2007 respectively and thus called the Catalogues, which list specific industries and even products and services in terms of encouraged, restricted or prohibited categories. Those not listed belong to the permitted category. The foreign investment in encouraged category often enjoys the right to establish WFOEs, while that in restricted category is often limited to JVs. Furthermore, other industry-specific regulations can make effect and may be taken priority over the Catalogues. Thus, ownership laws and regulations in China are complex.

\section{A Theoretical Framework}

Networks are important for firm behavior and even more important for firm growth in transitional economies (Peng \& Heath, 1996). Empirical studies provide evidence on the importance of network ties in China (e.g. Peng \& Luo, 2000). Although networks become less important and firm-specific capabilities are increasingly important with market-oriented institutional transitions (Peng, 2003), relationship networks in China enable firms to overcome institutional instability in the face of regulatory changes (Luo, 2003).

Strategic actions of firms are influenced by the social context in which they are embedded (Oliver, 1997). The link between networks and entry mode choice has been studied but controversial. As post-entry mode change is not studied so extensively as entry mode choice, previous research has not explicitly studied the link between networks and 
post-entry mode change. It is necessary to fill this gap. However, we are interested in their indirect link. From our perspective, networks can influence post-entry mode change indirectly through learning. Networks shape information flow, which in turn provides both opportunities and risks for firms and influences their strategic behavior (Gulati, 1999). To put it differently, learning about opportunities and risks through networks can affect firm strategic choice. With regard to this research, network and embeddedness become vehicles in learning Chinese ownership regulations of foreign investment and the learning affects post-entry mode change. Previous studies have highlighted the role of network and embeddedness in learning. Particularly, networks can be an external source for MNCs' acquiring foreign institutional knowledge. The network context is conceptualized as providing firms with valuable resources such as foreign institutional knowledge, which enables them to identify opportunities and risks. In addition, network embedded ties provide information benefits. Nevertheless, the effect of network and embeddedness on learning such specific host government policy as ownership regulations of foreign investment has not been studied before.

Meanwhile, whether experiential knowledge is positively or negatively related to post-entry mode change has been inconclusive. We cannot conclude from relevant research that accumulation of experiential knowledge either promotes or impedes the MNC subsidiary's mode change from joint venture to wholly foreign owned enterprise. According to the definition of organizational learning (Duncan \& Weiss, 1979, in Weick, 1991), Knowledge is the outcome of learning. Here, it is entailed to learning ownership regulations of foreign investment. We regard its essence as learning opportunities and risks that arise from the changing ownership regulations of foreign investment in China. The learning and resultant knowledge enables MNCs to exploit these opportunities and manage these risks. That is, learning ownership regulations affects MNC flexibility. MNC flexibility is among the factors that impact on post-entry mode change, as firm capability of dealing with environmental opportunities and risks is important to its strategic choice. Consequently, learning ownership regulations influences MNC flexibility, which in turn affects MNCs' post-entry mode change. In such an indirect way, learning ownership regulations could influence post-entry mode change. Thus, we develop the following theoretical framework:

$<$ Figure 1 about here $>$

\subsection{Network Types}

The task of defining a network involves specifying the set of nodes and the relationships between them (Laumann, Galaskiewicz, \& Marsden, 1978). Since our interest is in how networks affect learning ownership regulations, we define nodes as business and nonbusiness actors that form the network of acquiring, interpreting and confirming ownership regulations. These actors include both organizations and persons.

Thus, we divide network types into organizational level and personal level in this research. Inter-organizational networks refer to Hallen's (1992) inter-firm network and organization-centered infrastructural network, including organizational level business and non-business actors. Interpersonal networks are corresponding to Hallen's person-centered infrastructural network, including personal level business and non-business actors.

\subsection{Network Attributes}

Network structure, types of ties and strength of ties are important to competence, referred to as the ability to efficiently employ, acquire or develop other resources including among other things learning capabilities (Nooteboom, 2004). In other words, the above network attributes matter for learning capabilities, which also include learning ownership regulations.

Firms with superior network structures are able to enjoy higher benefits than those without such network structures (Arya \& Lin, 2007). As a feature of network structure, network size refers to the number of participants in the network (Nooteboom, 2004). The network size of an effective core network typically ranges from 12 to 18. However, it is even more important that core connections must bridge smaller, more-diverse kinds of groups and cross hierarchical, organizational, functional, and geographic lines (Cross and Thomas, 2011).

A firm's position occupied in the network characterizes its relationship with other firms. This position not only provides opportunities for development but also constrains future activities (Fletcher and Barrett, 2001). A firm with some network positions can better access to information than others. Centrality concerns how central a focal actor's position is relative to others in the network. Centrality refers to the position of an individual actor in the network and denotes the extent to which the focal actor occupies a strategic position in the network by virtue of being involved in many significant ties. High centrality implies a high position in a status hierarchy and high power (Wasserman \& Faust, 1994). High centrality leads to higher volume and speed of information flows (Gnyawali \& Madhavan, 2001; Lin, Yang, \& Demirkan, 2007). Both post-entry and subsequent entry mode choice involve international penetration, i.e. further developing positions in networks in the overseas country where the firm already has a position. 
Effective networks are made up of high-quality relationships with people who come from various groups. Strength of ties refers to the amount of time, the emotional intensity, the intimacy (mutual confidence) and the reciprocal services (Granovetter, 1973, in Hallen, 1992). Strong ties feature by high frequency and intensity and long duration, yielding shared experience, reducing cognitive distance, enabling development of empathy and identification (Hansen, 1999, in Nooteboom, 2004). Building trust is essential to sharing information (Coghlan and Coughlan, 2011). Strong ties help build trust and thus facilitate learning, particularly of complex knowledge, such as the changing and complex ownership regulations in China.

As another feature of network structure, density is defined as the extensiveness of exchange ties within the elements of the organization set in a specific country (Ghoshal \& Bartlett, 1990). Density has implication for access to information and knowledge. A dense network for exploration (i.e. a learning-based network with high density) enables actors to triangulate among multiple sources and better assess the meaning, value and reliability of the obtained information (Nooteboom, 2004).

Density is associated with strength of ties. Low density incurs absence of ties or arm's-length weak ties, leading to dominance of economic influences. High density is subject to strong embedded ties or multiple ties, resulting in greater influence of institutional factors or social context. Moreover, Coleman (1988, in Nooteboom, 2004) contended that a dense structure with strong ties helps build trust and social norms but constrains actions of network actors.

\subsection{Illustration}

We study network and embeddedness in terms of the above dimensions--network types and network attributes. Learning ownership regulations refers to acquiring, interpreting and confirming ownership regulations. The essence is to identify through networks opportunities and risks arisen from the changing ownership regulations of foreign investment in China. In order to deal with the changing institutional environment, MNCs particularly their subsidiaries in China, need to utilize their relationship networks for obtaining thick information that discloses veracity and meaning behind what policy says. MNC flexibility is defined as the MNC's ability to manage the risks and exploit the opportunities that arise from the changing ownership regulations of foreign investment in China. Thus, learning ownership regulations can be linked to MNC flexibility. Through identifying opportunities and risks arisen from the changing ownership regulations, MNCs are enabled to handle these opportunities and risks. Post-entry mode change is specified as the MNC subsidiary in China has changed to wholly foreign-owned enterprise (WFOE) after initial entry as joint venture (JV), which includes Chinese-foreign Cooperative Enterprise, Chinese-foreign JV and International JV (IJV). Since the ability to handle opportunities and risks from changing environment impacts on corporate strategy, MNC flexibility can exert influence over post-entry mode change. Thus, network and embeddedness, learning ownership regulations, MNC flexibility and post-entry mode change can be linked and put together into the previously stated framework. In terms of the two dimensions of networks, we specify the theoretical framework to the following proposition:

MNC subsidiary networks (both inter-organizational and interpersonal) with different network attributes are different in learning ownership regulations of foreign investment in China; difference in such learning leads to difference in MNC flexibility, which in turn leads to difference in post-entry mode change.

\section{References}

Andersson, U., Forsgren, M., \& Holm, U. (2002). The strategic impact of external networks: subsidiary performance and competence development in the multinational corporation. Strategic management journal, 23, 979-996, http://dx.doi.org/10.1002/smj.267

Arya, B. \& Lin, Z. (2007). Understanding Collaboration Outcomes from an Extended Resource-based View Perspective: The roles of organizational characteristics, partner attributes, and network structures. Journal of management. 33 (5), 697-723, http://dx.doi.org/10.1177/0149206307305561

Austen-Smith, D. (1987). Interest groups, campaign contributions, and probabilistic voting. Public choice, 54, 123-139, http://dx.doi.org/10.1007/BF00123002

Bahrami, H., \& Evans, S. (2005). Super-flexibility for knowledge enterprises. Berlin: Springer.

Barkema, H.G., Bell, J.H.J., \& Pennings, J. M. (1996). Foreign entry, cultural barriers, and learning. Strategic management journal, 17(2), 151-166, http://dx.doi.org/10.1002/(SICI)1097-0266(199602)17:2<151::AID-SMJ799>3.0.CO;2-Z

Bartlett, C.A., Ghoshal, S., \& Beamish, P.W. (2008). Transactional management: Text, cases, and readings in cross-border management. 5th ed., Singapore: McGraw-Hill.

Beamish, P.W. (1993). The characteristics of joint ventures in the People's Republic of China. Journal of international 
marketing, 1 (2), 29-48.

Bell, J. (1995). The internationalization of small computer software firms: A further challenge to Stage theories. European journal of marketing, 29(8), 60-75.

Boddewyn, J.J. (1988). Political aspects of MNE theory. Journal of international business studies, 19 (3), 341-362, http://dx.doi.org/10.1057/palgrave.jibs.8490392

Brouthers, K.D. \& Hennart, J-F. (2007). Boundaries of the firm: insights from international entry mode research. Journal of management, 33(3), 395-425, http://dx.doi.org/10.1177/0149206307300817

Buckley, P. \& Casson, M. (1981). The optimal timing of a foreign direct investment. Economic journal, 91(361), 75-87, http://dx.doi.org/10.2307/2231697

Chetty, S. \& Eriksson, K. (2002). Mutual commitment and experiential knowledge in mature international business relationship. International business review, 11(3), 305-324, http://dx.doi.org/10.1016/S0969-5931(01)00062-2

Chetty, S., \& Holm, D.B. (2000). Internationalization of small to medium-sized manufacturing firms: A network approach. International business review, 9(1), 77-93, http://dx.doi.org/10.1016/S0969-5931(99)00030-X

Coghlan, D. \& Coughlan, P. (2011). Transforming networks through network action learning. OD Practitioner, 43 (2), 2-6.

Coviello, N.E., \& Martin, K.A-M. (1999). Internationalization of service SMEs: An integrated perspective from the engineering consulting sector. Journal of international marketing, 7(4), 42-66.

Coviello, N.E., \& Munro, H. (1997). Network relationships and the internationalization process of small software firms. International business review, 6(4), 361-386, http://dx.doi.org/10.1016/S0969-5931(97)00010-3

Cross, R. \& Thomas, R. (2011) A smarter way to network. Harvard business review, July-August, 149-153, PMid:21800476

Delios, A., \& Beamish, P.W. (1999). Ownership strategy of Japanese firms: Transactional, institutional and experience influences. Strategic management journal, http://dx.doi.org/10.1002/(SICI)1097-0266(199910)20:10<915::AID-SMJ51>3.0.CO;2-0

Dicken, P. (1998). Global shift: Transforming the world economy. 3 rd ed. New York: Guilford Press.

Elango, B., \& Pattnaik, C. (2007). Building capabilities for international operations through networks: A study of Indian firms. Journal of international business studies, 38, 541-555, http://dx.doi.org/10.1057/palgrave.jibs.8400280

Eriksson, K., Johanson, J., Majkgard, A., \& Sharma, D.D. (1997). Experiential knowledge and cost in the internationalization process. Journal of international business studies, 28(2), 337-360, http://dx.doi.org/10.1057/palgrave.jibs.8490104

Eriksson, K., Johanson, J., Majkgard, A., \& Sharma, D.D. (2000). Effect of variation on knowledge accumulation in the internationalization process. International studies of management and organization, 30(1), 26-44.

Erramilli, M.K. (1991). The experience factor in foreign market entry behavior of service firms. Journal of international business studies, 22(3), 479-501, http://dx.doi.org/10.1057/palgrave.jibs.8490312

Fetscherin, M., Voss, H., \& Gugler, P. (2010). 30 Years of foreign direct investment to China: An interdisciplinary literature review. International business review, 19 (3), 235-246, http://dx.doi.org/10.1016/j.ibusrev.2009.12.002

Fletcher, R. \& Barrett, N. (2001) Embeddedness and the evolution of global networks: An Australian case study. Industrial Marketing Management, 30, 561-573, http://dx.doi.org/10.1016/S0019-8501(99)00120-0

Forsgren, M., Holm, U., \& Johanson, J. (2005). Managing the embedded multinational-A business network view. Cheltenham: Edward Elgar.

Ghoshal, S., \& Bartlett, C.A. (1990). The multinational corporation as an interorganizational network. Academy of management review, 15 (4), 603-625.

Giarratana, M.S., \& Torrisi, S. (2010). Foreign entry and survival in a knowledge-intensive market: Emerging economy countries' international linkages, technology competences, and firm experience. Strategic entrepreneurship journal, 4, 85-104.

Gnyawali, D.R., \& Madhavan, R. (2001). Cooperative networks and competitive dynamics: A structural embeddedness perspective. Academy of management review, 26 (3), 431-445. 
Gomes-Casseres, B. (1990). Firm ownership preferences and host government restrictions: An integrated approach. Journal of international business studies, 21(1), 1-22, http://dx.doi.org/10.1057/palgrave.jibs.8490324

Granovetter, M. (1985). Economic action and social structure: The problem of embeddedness. American journal of sociology, 91(3), 481-510, http://dx.doi.org/10.1086/228311

Gulati, R. (1995). Does familiarity breed trust: The implications of repeated ties for contractual choice in alliances. Academy of management journal, 38, 85-112, http://dx.doi.org/10.2307/256729

Gulati, R. (1999). Network location and learning: the influence of network resources and firm capabilities on alliance formation. Strategic management journal, 20, 397-420, http://dx.doi.org/10.1002/(SICI)1097-0266(199905)20:5<397::AID-SMJ35>3.0.CO;2-K

Gulati, R., \& Singh, H. (1998). The architecture of cooperation: managing coordination costs and appropriation concerns in strategic alliances. Administrative science quarterly, 43, 781-814, http://dx.doi.org/10.2307/2393616

Hadjikhani, A. (2000). The political behavior of business actors: The case of Swedish MNCs and the EU. International studies of management and organization, 30 (1), 93-117.

Hadjikhani, A., \& Ghauri, P.N. (2001). The behavior of international firms in socio-political environments in the European Union. Journal of business research, 52, 263-275, http://dx.doi.org/10.1016/S0148-2963(99)00106-X

Hadjikhani, A., \& Hakansson, H. (1996). Political actions in business networks: A Swedish case. International journal of research in marketing, 13 (5), 431-447, http://dx.doi.org/10.1016/S0167-8116(96)00024-9

Hagedoorn, J., \& Duysters, G. (2002). Learning in dynamic inter-firm networks: The efficacy of multiple contacts. Organization studies, 23(4), 525-548, http://dx.doi.org/10.1177/0170840602234002

Hakansson, H., \& Snehota, I. (1989). No business is an island: The network concept of business strategy. Scandinavian journal of management, 5 (3), 187-200, http://dx.doi.org/10.1016/0956-5221(89)90026-2

Hakansson, H., \& Snehota, I. (2000). The IMP perspective: Assets and liabilities of business relationships. In J.N. Sheth, \& A. Parvatiyar. Handbook of relationship marketing (pp. 69-93). Thousand Oaks: Sage.

Halinen, A., \& Tornroos, J.-A. (1998). The role of embeddedness in the evolution of business networks. Scandinavian journal of management, 14 (3), 187-205, http://dx.doi.org/10.1016/S0956-5221(98)80009-2

Hallen, L. (1992). Infrastructural networks in international business. In M. Forsgren, \& J. Johanson. Managing networks in international business (pp. 77-92). Philadelphia, PA: Gordon and Breach.

Hamel, G. (1991). Competition for competence and inter-partner learning within international strategic alliances. Strategic Management Journal, 12 (summer), 83-103.

Hedlund, G., \& Kverneland, A. (1985). Are entry strategies for foreign markets changing? The case of Swedish investments in Japan. International studies of management and organization, 15(2), 41-59.

Helper, S. (1990). Comparative supplier relations in the US and Japanese auto industries: An exit-voice approach. Business economic history, 19, 153-162.

Hennart, J.-F. (1991). The transaction costs theory of joint ventures: An empirical study of Japanese subsidiaries in the United States. Management science, 37 (4), 483-497, http://dx.doi.org/10.1287/mnsc.37.4.483

Jansson, H., Saqib, M., \& Sharma, D.D. (1995). The state and transnational corporations: A network approach to industrial policy in India. Aldershot: Edward Elgar.

Johanson, J., \& Vahlne, J. (1977). The internationalization process of the firm-A model of knowledge development and increasing foreign market commitments. Journal of international business studies, 8(1), 23-32, http://dx.doi.org/10.1057/palgrave.jibs.8490676

Johanson, J., \& Vahlne, J. (2003). Business relationship learning and commitment in the internationalization process. Journal of international entrepreneurship, 1(1), 83-101, http://dx.doi.org/10.1023/A:1023219207042

Johanson, J., \& Vahlne, J. (2009). The Uppsala internationalization process model revisited: From liability of foreignness to liability of outsidership. Journal of international business studies, 40, 1411-1431, http://dx.doi.org/10.1057/jibs.2009.24

Kogut, B. (1985). Designing global strategies: profiting from operating flexibility. Sloan management review, Fall, 27-38. 
Kogut, B. (2000). The network as knowledge: Generative rules and the emergence of structure. Strategic management journal, 21 (3), 405-425, http://dx.doi.org/10.1002/(SICI)1097-0266(200003)21:3<405::AID-SMJ103>3.0.CO;2-5

Larson, A. (1992). Network dyads in entrepreneurial settings: A study of the governance of exchange processes. Administrative science quarterly, 37, 76-104, http://dx.doi.org/10.2307/2393534

Laumann, E.O., Galaskiewicz, J., \& Marsden, P.V. (1978). Community structure as interorganizational linkages. Annual review of sociology, 4, 455-484, http://dx.doi.org/10.1146/annurev.so.04.080178.002323

Lin, Z., Yang, H., \& Demirkan, I. (2007). The performance consequences of ambidexterity in strategic alliance formations: Empirical investigation and computational theorizing. Management science, 53(10), 1645-1658, http://dx.doi.org/10.1287/mnsc.1070.0712

Loane, S., \& Bell, J. (2006). Rapid internationalization among entrepreneurial firms in Australia, Canada, Ireland and New Zealand. International marketing review, 23(5), 467-485, http://dx.doi.org/10.1108/02651330610703409

Luo, Y. (2003). Industrial dynamics and managerial networking in an emerging market: The Case of China. Strategic management journal, 24 (13), 1315-27, http://dx.doi.org/10.1002/smj.363

Madhavan, R., Koka, B.R., \& Prescott, J.E. (1998). Network in transition: How industry events (re)shape interfirm relationships. Strategic management journal, 439-459, http://dx.doi.org/10.1002/(SICI)1097-0266(199805)19:5<439::AID-DIA952>3.0.CO;2-2

Madhok, A. (1997). Cost, value and foreign market entry mode: The transaction and the firm. Strategic management journal, 18, 39-61.

Moen, O., Gavlen, M., \& Endresen, I. (2004). Internationalization of small, computer software firms: Entry forms and market selection. European journal of marketing, 38(9-10), 1236-1251, http://dx.doi.org/10.1108/03090560410548951

Moran, T.H. (1985). Multinational corporations: The political economy of foreign direct investment. Lexington, MA: Lexington Books.

Murtha, T.P., \& Lenway, S.A. (1994). Country capabilities and the strategic state: How national political institutions affect multinational corporations' strategies. Strategic management journal, 15, 113-129, http://dx.doi.org/10.1002/smj.4250151008

Nooteboom, B. (2004). Inter-firm collaboration, learning and networks: An integrated approach. New York: Routledge.

Ojala, A. (2009). Internationalization of knowledge-intensive SMEs: The role of network relationships in the entry to a psychically distant market. International business review, 18, 50-59, dhttp://dx.doi.org/10.1016/j.ibusrev.2008.10.002

Oliver, C. (1997). Sustainable competitive advantage: Combining institutional and resource-based views. Strategic $\begin{array}{llll}\text { management } & \text { journal, } & 18 & (9),\end{array}$ http://dx.doi.org/10.1002/(SICI)1097-0266(199710)18:9<697::AID-SMJ909>3.0.CO;2-C

Parke, A. (1993). Strategic alliance structuring: A game theoretic and transaction cost examination of interfirm cooperation. Academy of management journal, 36 (4), 794-829.

Peng, M.W. (2003). Institutional transitions and strategic choices. Academy of management review, 28 (2), 275-296.

Peng, M.W., \& Heath, P.S. (1996). The growth of the firm in planned economies in transition: institutions, organizations, and strategic choice. Academy of management review, 21 (2), 492-528.

Peng, M. W., \& Luo, Y. (2000). Managerial ties and firm performance in a transition economy: The nature of a micro-macro link. Academy of management journal, 43(3), 486-501, http://dx.doi.org/10.2307/1556406

Powell, W.W. (1990). Neither market nor hierarchy: Network forms of organization. Research in organizational behavior, 12, 295-336.

Puck, J.F., Holtbrugge, D., \& Mohr, A.T. (2009). Beyond entry mode choice: Explaining the conversion of joint ventures into wholly owned subsidiaries in the People's Republic of China. Journal of international business studies, 40, 388-404, http://dx.doi.org/10.1057/jibs.2008.56

Rangan, S. (2000). Search and deliberation in international exchange: micro foundations to some macro patterns. Journal of international business studies, 31(2), 205-222, http://dx.doi.org/10.1057/palgrave.jibs.8490902

Romo, F.P., \& Schwartz, M. (1995). Structural embeddedness of business decisions: A sociological assessment of the 
migration behavior of plants in New York State between 1960 and 1985. American sociological review, 60, 874-907, http://dx.doi.org/10.2307/2096431

Root, F. R. (1994). Entry strategies for international markets. San Francisco: Lexington Books.

Sharma, D. D., \& Blomstermo, A. (2003). The internationalization process of born globals: A network view. International business review, 12 (6), 739-753, http://dx.doi.org/10.1016/j.ibusrev.2003.05.002

Smitka, M. (1991). Competitive ties: Subcontracting in the Japanese automotive industry. New York: Columbia University Press.

Sydow, J., \& Windeler, A. (1998). Organizing and evaluating interfirm networks: A structurationist perspective on network processes and effectiveness. Organization science, 9 (3), 265-284, http://dx.doi.org/10.1287/orsc.9.3.265

Teece, D.J. (1986). Profiting from technological innovation. Research policy, 15 (6), 285-305, http://dx.doi.org/10.1016/0048-7333(86)90027-2

Uzzi, B. (1996). The sources and consequences of embeddedness for the economic performance of organizations: The network effect. American sociological review, 61(4), 674-698, http://dx.doi.org/10.2307/2096399

Uzzi, B. (1997). Social structure and competition in interfirm networks: The paradox of embeddedness. Administrative science quarterly, 42, 35-67, http://dx.doi.org/10.2307/2393808

Vyas, N.M., Shelburn, W.L., \& Rogers, D.C. (1995). An analysis of strategic alliances: Forms, functions and framework. Journal of business and industrial marketing, 10 (3), 47-60, http://dx.doi.org/10.1108/08858629510147466

Wasserman, S., \& Faust, K. (1994). Social network analysis: Methods and applications. New York: Cambridge University Press.

Welch, C., \& Wilkinson, I. (2004). The political embeddedness of international business networks. International marketing review, 21(2), 216-231, http://dx.doi.org/10.1108/02651330410531411

Xia, J., Tan, J. and Tan, D. (2008) Mimetic entry and bandwagon effect: the rise and decline of international equity joint venture in China. Strategic Management Journal, 29, pp. 195-217, http://dx.doi.org/10.1002/smj.648

Zain, M., \& Ng, S. I. (2006). The impacts of network relationships on SMEs' internationalization process. Thunderbird international business review, 48(2), 183-205, http://dx.doi.org/10.1002/tie.20092

Zhang, S., \& Li, X. (2008). Managerial ties, firm resources, and performance of cluster firms. Asia pacific journal of management, 25, 615-633, http://dx.doi.org/10.1007/s10490-008-9090-7

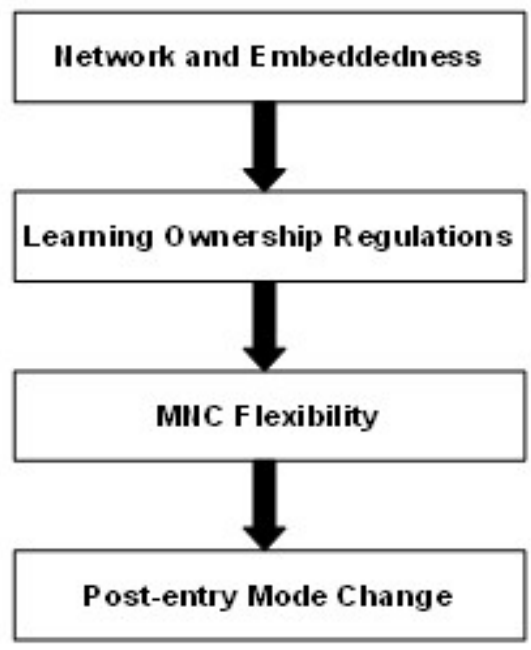

Figure 1.

Difference in network and embeddedness leads to difference in learning ownership regulations of foreign investment in China, which in turn leads to difference in MNC flexibility, which in turn leads to difference in post-entry mode change of MNC subsidiaries 